\title{
Developing the Value of Character Education for Junior High School Students through Folklore Ngembel Spring Water
}

\author{
Anin Akvian Perbawani ${ }^{1}$, Sarwiji Suwandi ${ }^{2}$, and Slamet Subiyantoro ${ }^{3}$ \\ \{aninakvian@student.uns.ac.id ${ }^{1}$, sarwijiswan@staff.uns.ac.id ${ }^{2}, \&$ \\ s.subiyantoro@staff.uns.ac.id $\left.{ }^{3}\right\}$ \\ ${ }^{1,2,3}$ Universitas Sebelas Maret, Surakarta, Indonesia
}

\begin{abstract}
Folklore can be used as one of teaching materials. The purpose of using folklore is to stimulate students in order to develop their positive characters. In addition, folklore is used in teaching for preserving Indonesian history which gradually disappears in the midst of digital era. The present research applies descriptive qualitative research method. Meanwhile, the research approach applied is ethnographic approach. In order to get rich results, the present research also obtains the data from documents and interview. Passive observation technique is also applied within this research. Open-ended interview is also implemented. This research also uses data analysis method in which it has three components of interactive analysis, namely data reduction, data display, and conclusion drawing. The results suggest that there are nine values of character education learned from the characters' attitude and description including 1) tolerance, 2) gratitude, 3) perseverance, 4) wisdom, 5) affection, 6) fortitude, 7) justice, 8) positive attitude and 9) modesty.
\end{abstract}

Keywords: folklore, value of character education, tolerance

\section{INTRODUCTION}

It is frequently found that there are many cases of violence between teachers and students. This issue emerged cannot be separated from character education that students learn both in formal and informal education. It is also argued that students' character is influenced by culture and customs as well as social environment where they are from. Therefore, it is necessary to reinforce character education for students in order to form them to have positive attitude, good and modest characters towards social norms.

Education is the main factor for developing students with strong characters as the means to establish high and superior civilization. A nation gets strong is the result of good quality of education [1]. School is one of the most important places to teach character education to children. The learning curriculum requires students to spend most of their time in school instead of their home. That is why school gains more attention for it is the place where students can develop their positive attitude. The most important actor in improving students' moral conviction lies on the principal who acts as a leader so that an organized and 
encouraging atmosphere for teachers, students, and the entire school elements can be created $[2]$.

Furthermore, character building should be based on human moral values in society, both as an individual and a group [3]. The purpose of education is to turn human into a clever, wise, and critical individual. In fact, with education, human can become pious, conscious, honest and responsible [4]. Literary lesson is expected to be one of the teaching material alternatives to build positive attitude of junior high school students. The existence of oral literature in social life is the reflection of solidarity and identity which has particular aims [5].

There are several ways which can be done in teaching character education; one of them is using folklore. This becomes essential for character is not inherited, but formed and developed continuously through thoughts and actions since birth until elderly [6]. Character becomes special and unique when it is different from others. Hence, the habit and routine related to character building is expected to successfully form students' good character. In addition, the effectiveness of folklore as a teaching alternative is suitable to be used during listening lesson [7]. In order to design popular folklore among society, it should be modified and needs continuous supporting activities that are carried out both in school and society [8].

The advantage of folklore comprises of moral values it has which is the heritage from generation to generation. This is therefore confirms that folklore can be used to strengthen character education [9]. Literature works that are about to used should be selected in advance and adjusted with teaching objects based on it as well. In Indonesia, there are plenty of various literature works and they are written by numerous authors [10]. However, not all works can be used to build character because some are tragedy and others are comedy. Only the former one can be used in character building. Additionally, lessons or materials for literature work in curriculum have been chosen in terms of its genres, not topic, such as poetry, short story, novel, or drama. Normally, authors of the book decide the topic of the work.

Development of character education through folklore in Bantul, Yogyakarta can be researched and used as teaching materials. Folklore is a literature work in which its content can be used as the benchmark of exemplary and personality of story's characters or description. Furthermore, the research on folklore is useful for preserving Indonesian history. The folklore entitled Ngembel Spring Water tells about a journey of a leader who wanted to save his subjects from drought. His effort to flow water was helped by his servants and his wife. Eventually, Ki Ageng Mangir and Kyai Jalumampang were successful in streaming water from the spring in which until today is still flowing.

\section{METHOD}

This research is a qualitative research with study object referring to folklore. The present research is descriptive qualitative. The approach used is ethnographic approach. Ethnography is to collecting information and data which are done systematically in regards to way of life, social activity, and cultural objects from society [11]. The sources of data collection within this research are through documents and interview. Data obtained in this research is the folklore of Bantul regency. In addition, the source data are taken from the interviewee who understands the folklore of Ngembel Spring Water in Bantul Regency. Data collection technique used in this research is passive observation, whereas the interview is open-ended in which the researcher do not use interview guideline. This research also uses data analysis method in which it has three components of interactive analysis, namely data reduction, data display, and conclusion drawing. 


\section{RESULT AND DISCUSSION}

Folklore is divided into two compound words, namely folk and lore. Folk refers to a group of people who have physical, social and cultural identification characteristics [12]. This, therefore, allows them to be recognized easier than other groups. Most importantly, they have had custom and tradition inherited from generation to generation. Hence, folklore has physical identification within a community group.

Folklore contains cultural values that can be benefited as educational source. Cultural values in folklore genre refer to the messages as a source of knowledge or education for the next generation. In its essence, genre of folklore is a cultural expression which has values that can be emulated and internalized by future generation. Value system has a central position in the cultural structure of society. It also becomes a phenomenon and problem in the basis of human's life [13]. In this research, it focuses on the legendary folklore of Bantul Regency in Yogyakarta entitled Ngembel Spring Water. Legend is one of oral literature works which exists in a community as a manifestation of society's certain conditions [14]. Below is the quotation from Ngembel Spring Water folklore which has values of character education.

While his father was climbing coconut trees and nderes legen to make palm sugar, his mother was cleaning dried green coconut leaves to be made as a broom. Once in a while, fathers do not only take legen home, but also bring young manggar (trash of coconut) which will be cooked to be gudeg manggar. Well, almost all parts of Mangir's territory are filled with coconut tree, which does not only make the environment shooting, but also provide the community source of food.

The quotation above depicts tolerance among family members who always help each other. A father climbed coconut trees in order to find nderes legen (raw material for making palm sugar); a mother cleaned dried coconut leaves in order to make a broom. This quotation then describes that tolerance in a family will make the relation even more harmonious among one another.

Teak and mahogany trees are selected because plenty of them grow around the wood and they also have a good and strong wood quality to be made as pillars. Kyai Jalumampang cut down the big trees only using machete.

The hardworking quality of the character is shown by a persevering leader (Kyai Jalumampang) who was looking for woods on his own to survive. These things are done by himself, starting from cutting down trees to making pillars.

Although he was known for being powerful and having rebellious soul, Ki Ageng Mangir is the figure of a wise leader to his people. He was able be aware of his people suffering without having to find out.

In spite of being known to have rebellious character, Ki Ageng Mangir should be looked up to in order to protect his people. He knew well when the people were insufferable. He did not need to act harsh because he could control himself as a leader.

"In the following day, early in the morning, I'll be heading to Mataram to ask for permission from Panembahan to let water spring flow into the fields of the people”, said Kyai Jalumampang. 
There are several positive behaviors shown by Kyai Jalumampang within this folklore. One of them is he stayed calm when finding a solution to a problem as well as in taking decision to go asking for permission to flow the spring to the people's fields.

In the afternoon, Kyai Jalumampang returned from palace to ask for permission from the King of Mataram to stream water from spring to the fields of the people.

Being modest is a necessary quality that should be owned by a leader. Having a power does not make him hesitate to ask permission by himself so that he subjects can be prosperous and saved from drought. Such example should be imitated by each individual.

Since both of them are the people of wisdom and based on the revelation received by Kyai Juwo, then they were in agreement to divide the spring into two parts.

The lesson learned from this folklore Ngembel Spring Water is the quality of being just. It can be seen from them being relieved when accepting the agreement without any arguments. This indicates that being just leads us to be a wise human.

In the morning, once they arrived in the Mentaok field, Kyai Jalumampang immediately started to build a hut as the place to stay.

In such a severe drought, Kyai Jalumampang kept patient and survived. He still tried to build a hut as a replacement of his home in the jungle. This quality of Kyai Jalumampang teaches that no matter how hard the situation is, there must be a way out. Therefore, being patient should be inside us.

How can I eat peacefully, Nyai when I realize that my people are suffering. The rice that about to be harvested has been damaged due to drought. It is hard for them to drink, let alone to eat.

Love, care and affection from a leader to his people was proven when Ki Ageng Mangir listened to his people's complaints who were in the midst of difficulties in finding water and their crops got damaged. He looked sad because he did not have the heart to witness their suffering. This becomes the evidence that Ki Ageng Mangir cared about his people.

To show gratitude, the people celebrate the spring by holding a Baritan ceremony. In this event, the people bring offering, such as rice, dish, sticky rice, compote, and apem as the manifestation of their gratitude because their fields were never in drought.

Such thankfulness is depicted in the folklore through one of the quotation that Mangir people, Bantul Regency, carried out offering ceremony by bringing their crops because there were no more droughts. Another lesson that can be learned here is when receiving something, we should be thankful so that we get blessing. Some quotations above describe that folklore Ngembel Spring Water can be used as an teaching material alternative in developing character education. There are nine education characters obtained here, namely tolerance, gratitude, perseverance, wisdom, affection, fortitude, justice, positive attitude and modesty. It is expected that young generation can learn from these and become a person with better personality in this era. Another thing is literature works can also be as the character building. The experiences obtained through reading literature works can motivate and support students' cognitive and reasoning development. As a result, students can get their ability to express their 
emotion, empathy to one another, as well as develop their feeling about themselves and their identity [15]. The difference between the present research and the research done by Wulandari is that there are several quotations that can be the concrete examples for junior high school students to look up to characters with wisdom within this folklore Ngembel Spring Water. In addition, in social life, students can live and have good characters. Both oral and written literature works can be used as stimulus and teaching material alternative in junior high schools [16][17].

\section{CONCLUSION}

Folklore Ngembel Spring Water is a legend that is told orally coming from Bantul Regency, Yogyakarta that has the evidence of relic in the form of the spring or a pond that comes from a spring. The spring still exists until today. In this research, it is found that there are nine character education learned from the folklore, such as 1) tolerance, 2) gratitude, 3) perseverance, 4) wisdom, 5) affection, 6) fortitude, 7) justice, 8) positive attitude and 9) modesty. Attitude and behaviors shown by the characters as well as the story's description of this folklore are able to be used as the teaching material for junior high school students in particular. Furthermore, it is used for teaching history to students in which they can preserve the folklore. The characters shown in the folklore Ngembel Spring Water is expected to be a benchmark for young generation to keep their true identity in the globalization.

\section{REFERENCE}

[1] S. B. Raharjo, "Pendidikan Karakter Sebagai Upaya Menciptakan Akhlak Mulia," J. Pendidik. dan Kebud., vol. 16, no. 3, p. 229, 2018.

[2] A. Abdullah, "Cultivating Morals Students through Character Education: A Case Study," J. Educ. Learn., vol. 12, no. 3, p. 457, 2018.

[3] S. Wening, "The nation's character building through value education," J. Pendidik. Karakter, vol. 2, no. 1, pp. 55-66, 2012.

[4] N. luh L. A. Dewi, I. B. Putrayasa, and I. G. Nurjaya, "Analisis Nilai-Nilai Pendidikan Karakter Novel Sepatu Dahlan Karya Khrisna Pabichara Dan Karakter Sekolah Di Indonesia," e-Jurnal Pendidik. dan Sastra Indones., vol. 2, no. 1, pp. 1-10, 2014.

[5] E. Irzal Amin, Syahrul R, "Cerita Rakyat Penamaan Desa di Kerinci: Kategori dan Fungsi Sosial Teks,” Bahasa, Sastra dan Pembelajaran, vol. 1, no. 2, pp. 31-41, 2013.

[6] Bambang Suryadi, "PENDIDIKAN KARAKTER: SOLUSI MENGATASI KRISIS MORAL BANGSANo Title," NIZHAM, vol. 4, no. 2, pp. 71-84, 2015.

[7] H. A. Pitaloka, W. Siswanto, and Martutik, "Dokumentasi Cerita Rakyat Malang Raya dan Pengembangan Media Pembelajaran Menyimak," vol. 437, no. 1991, pp. 1-19, 1994.

[8] M. Janthaluck and W. O. (Laila), "Folklore, Restoration of Social Capital and Community Culture," Procedia - Soc. Behav. Sci., vol. 65, no. ICIBSoS, pp. 218-224, 2013.

[9] Ayu Puspita Indah Sari, "PENGUATAN PENDIDIKAN BERKARAKTER PESERTA DIDIK MELALUI NILAI MORAL PADA CERITA RAKYAT 'SEMBESAT SEMBESIT," PROCEEDING Semin. Nas. Pendidik. Bhs. Indones., vol. 2, no. 1, pp. 207-216, 2018.

[10] L. Septiningsih, "Membangun Karakter Bangsa Berbasis Sastra: Kajian terhadap Materi Karya Sastra di Sekolah Menengah Atas," J. Pendidik. dan Kebud., vol. 21, no. 1, p. 71, 
2018.

[11] Suwardi Endraswara, Metode, Teori Teknik Penelitian Kebudayaan: Ideologi, Epistemologi, dan Aplikasi. Yogyakarta: Pustaka Widyatama, 2006.

[12] M.Rafiek, Teori Sastra: Kajian Teori dan Praktek. Bandung: PT. Refika Aditama, 2010.

[13] Suwardi Endraswara, FOLKLOR NUSANTARA Hakikat, Bentuk, dan Fungsi. Yogyakarta: Penerbit Ombak, 2013.

[14] L. Rustanti and B. Indiatmoko, "Ajaran dan Pemikiran Sunan Kalijaga pada Legenda Penamaan Desa di Masyarakat Demak," Seloka J. Pendidik. Bhs. dan Sastra Indones., vol. 6, no. 3, pp. 265-272, 2017.

[15] R. A. Wulandari, "Sastra dalam pembentukan karakter siswa," J. Edukasi Kult., vol. 2, no. 2, pp. 63-73, 2015.

[16] K. Saddhono and M. Rohmadi, "A Sociolinguistics Study on the Use of the Javanese Language in the Learning Process in Primary Schools in Surakarta, Central Java, Indonesia." Int. Edu. Stu., vol. 7 no.6 pp 25-30, 2014

[17] K. Saddhono, "Cultural and social change of foreign students in Indonesia: The influence of Javanese Culture in Teaching Indonesian to Speakers of Other Languages (TISOL)." IOP Conf. Ser.: Ear. and Envi. Sci.. vol. 126 no. 1 IOP Publishing, 2018. 